\title{
Effect of Socioeconomic status on performance in Mathematics among students of secondary schools of Guwahati city
}

\author{
Gunendra Chandra Das ${ }^{1}$, Sujan Sinha ${ }^{2}$ \\ ${ }^{1}$ Assistant Professor, Dept. of Mathematics, Assam down town University, India \\ ${ }^{2}$ Assistant Professor, Dept. of Mathematics, Assam down town University, India
}

\begin{abstract}
Socio-economic status' (SES) is a term used by social scientists and sociologists to describe the position of an individual in a hierarchical social structure which includes both the social and economic status. In looking more closely at why a remarkable number of students may be struggling for improvement in mathematics in comparison to other subjects, it is timely to consider, the SES factor. This study intends to investigate how parents' SES affects their children's performance in that subject. The study adopted a descriptive survey design and data was largely descriptive by nature. Data were collected using questionnaires for the students of $9^{\text {th }}$ standard. These were administered on a sample of 384 students selected from 13 secondary and senior secondary schools of Guwahati city. The internal reliability and validity were examined. The formulae used for internal reliability were Split-half reliability and Cronbach Alpha. Data collected were coded and subjected to SPSS analysis which indicates overall that parents' socioeconomic status affects their children's performance in the subject.
\end{abstract}

Keywords: Socioeconomic status, mathematical performance.

\section{Introduction}

'Socio-economic status' (SES) is a term used by social scientists and sociologists to describe the position of an individual in a hierarchical social structure. Socio-economic status includes both the social and economic status of an individual in the group. Sawrey and Telford [1] opined that children from higher socioeconomic status are not only brilliant but they also get better opportunities for intellectual, physical and emotional developments. Studies have repeatedly established that SES affects student's outcomes [2,3]. In [4] it has been revealed that the academic performance was influenced by socio-economic status of the children.'Socio-economic status' may include so many factors such as parental education, occupation, income etc. Velez, Schiefelbein and Valenzuella [5] concluded in their studies that socio-economic status measured by parents' education or occupational status is positively associated with achievement in most of the cases.

Extensive research in the sociology of education offers conclusive evidence of a positive relationship between family socio-economic status (SES) and the academic achievement of students [6,7]. SES as the relative position of individuals or families within a hierarchical social structure, based on their access to, or control over, wealth, prestige, and power [8], although no strong consensus exists on the conceptual meaning of SES [9]. And, a single SES variable is operationalized through the components parental education, parental occupational prestige, and family income $[8,10,11]$.

In society it is known to all that educational outcomes of children vary with the socio-economic background of their parents. Home is the first school of children. Home environment at influences a child's school education with his/her aspirations towards a good citizen for the future. As the children of today will be the nation builder of tomorrow, it is significantly essential to run the children's educational programmes very sincerely and effectively. Through scientific-designed and fruitfully implemented educational programmes children can be made equipped with necessary knowledge, skills and moral values. Family has also an important role in all-round development of the school children. Parents or guardians have to take a great responsibility in promoting societal knowledge, behavioral aspects, attitude etc. The facilities and environments provided to a student to study, is the basis for his success [12]. Socio-economic status can play both positive and negative role in the future life of a student [13].

Thus, to study the children's achievement in a particular subject, it is very much important to investigate their family background or in other words 'socio-economic status' of their family. The study on the effects of socio-cultural factors on psychological characteristics of individuals has been placed as an important in the contemporary psychological research, but, very few numbers of studies have been worked so far in this area. Khan and Jemberu [14] studied the influence of socioeconomic status on educational and occupational aspirations of high and low achieving adolescents.

In the present study, the effect of socio-economic status on performance in mathematics of secondary level students has been investigated. 


\section{Objectives}

To analyze the socio-economic status of secondary school students.

- To test the association between socio-economic status and performance of students in mathematics

- To test the correlation between socio-economic status and performance of students in mathematics.

- To study the effect of socio-economic status of students of different category of schools such as provincialised under SEBA (Secondary Education Board of Assam), private under SEBA and private schools under CBSE (Central Board of Secondary Education) on their performance in mathematics.

\section{Hypothesis}

Different null hypotheses which we assumed for our investigation are-

1. There is no significant difference between mean 'socio-economic status' scores of students from different categories of schools.

2. There is no significant association between 'socio-economic status' and 'performance in mathematics' of students.

3. There is no significant correlation between 'socio-economic status' and 'performance in mathematics' of students.

4. There is no significant effect of 'socio-economic status' on 'performance in mathematics' of students from different categories of schools.

\section{Samples}

In our study, for selection of samples, stratified random sampling technique has been adopted. The schools from which students of IX standard are considered as samples, have been stratified into three strataprovincialised schools under SEBA (Board of Secondary Education Assam), private schools under SEBA and private schools under CBSE(Central Board Of Secondary Educatiion) of Guwahati city. The samples from each stratum are taken through simple random sampling technique. The stratification is done to produce a gain in precision in the estimates of characteristics of the whole population. All the students of IX standard from private, govt., provincialiseed including SEBA and CBSE of the city formed the population of our study. At $95 \%$ confidence level with $+5 \%$ level of precision, the estimated sample size from a total of 12531 was found to be 384 . This sample size of 384 students from 13 selected schools are considered to be representative samples.

\section{Socio-Economic Status (SES) scale questionnaire}

\section{Tools}

To assess socio-economic status of the parents of the sample students under the study, the socioeconomic status scale questionnaire was used. The questionnaire was designed fully on the basis of the socioeconomic status scale, updated version developed by B. Kuppuswamy. In the studies Kumar N, et al [15]; Mishra, D.and Singh, H.P [16] it has been revealed that due to the steady inflation and consequent fall of the valuation of the rupee, economic criteria, income scale to be relevant, it should be considered during the period of study. Popular and widely used this Kuppuswamy scale is used in the study to measure the socio-economic status of an individual. In the study, the CPI-IW for October, 2015 was 269 (http://labourbureau.nic.in/indexes.htm). Three primary variables have been emphasized in this questionnaire the education, and occupation of the head of a family and monthly income of the family. The modified family income for 2015 in the month of October was found as in the Table 3.4. The questionnaire was administered on the parents concerned. The range of score point is from 3 to 29 . Based on the scores obtained by the parents, the families were classified in terms of socio-economic status (Table I).

Table-I: Modified family income per month (in Rs)

\begin{tabular}{|c|c|c|c|c|c|c|c|c|}
\hline $\begin{array}{c}\text { Score } \\
\text { point }\end{array}$ & $\begin{array}{c}\text { Modified } \\
\text { (for the } \\
\text { year 1998) }\end{array}$ & $\begin{array}{c}\text { Modified } \\
\text { (for the } \\
\text { year 2007) }\end{array}$ & $\begin{array}{c}\text { Modified (for } \\
\text { the year } \\
\mathbf{2 0 0 8}\end{array}$ & $\begin{array}{c}\text { Modified (for } \\
\text { the year } \\
\mathbf{2 0 0 9}\end{array}$ & $\begin{array}{c}\text { Modified (for } \\
\text { the year } \\
\text { 2010) }\end{array}$ & $\begin{array}{c}\text { Modified (for } \\
\text { the year 2011) }\end{array}$ & $\begin{array}{c}\text { Modified (for the } \\
\text { year 2012) }\end{array}$ & $\begin{array}{c}\text { Modified } \\
\text { for the year } \\
\mathbf{2 0 1 5}(\text { Oct) } \\
\text { (CPI-269) }\end{array}$ \\
\hline 12 & $\geq 13500$ & $\geq 19575$ & $\geq 22410$ & $\geq 25785$ & $\geq 27675$ & $\geq 28754$ & $\geq 32050$ & $\geq 41,488$ \\
\hline 10 & $6750-13499$ & $9788-19575$ & $11205-22409$ & $12892-25784$ & $13837-27674$ & $14376-28753$ & $16020-32049$ & $20,744-$ \\
\hline 6 & $5050-6749$ & $7323-9787$ & $8383-11204$ & $9645-12891$ & $10352-13836$ & $10755-14375$ & $12020-16019$ & $15,558-$ \\
\hline 4 & $3375-5049$ & $4894-7322$ & $5602-8382$ & $6446-9644$ & $6919-10351$ & $7188-10754$ & $8010-12019$ & $10,372-$ \\
\hline 3 & $2025-3374$ & $2936-4893$ & $3361-5601$ & $3867-6445$ & $4151-6918$ & $4312-7187$ & $4810-8009$ & $6,223-$ \\
\hline 2 & $676-2024$ & $980-2935$ & $1122-3360$ & $1291-3866$ & $1386-4150$ & $1439-4311$ & $1601-4809$ & $2,095-$ \\
\hline 1 & $\leq 675$ & $\leq 979$ & $\leq 1121$ & $\leq 1290$ & $\leq 1384$ & $\leq 1438$ & $\leq 1600$ & $\leq 2,094$ \\
\hline
\end{tabular}


Effect of Socioeconomic status on performance in Mathematics among students of secondary ..

Table-II: Classification of socioeconomic status (SES)

\begin{tabular}{|c|c|}
\hline SES class & Score point \\
\hline Upper class (UC) & $26-29$ \\
\hline Upper middle class (UMC) & $16-25$ \\
\hline Lower middle class (LMC) & $11-15$ \\
\hline Upper lower class (ULC) & $5-10$ \\
\hline Lower class (LC) & $<5$ \\
\hline
\end{tabular}

\subsection{Reliability of ses questionnaire}

The Cronbach Alpha for the questionnaire we used for our study was found to be 0.73 , which is greater than 0.70 agreeing with the recommendation that for an instrument to be used, its internal co-efficient, Chronbach's alpha must be at least $0.70,[17]$.

\subsection{Validity of SES questionnaire}

In this case, the reliability coefficient is 0.73 . Hence, the index of reliability is 0.85 . The present index of reliability implies that the test measures true ability of the subjects to the extent of $85 \%$. That means the validity of the questionnaire is 0.85 .

Table-III: Parents' Demographic Characteristics

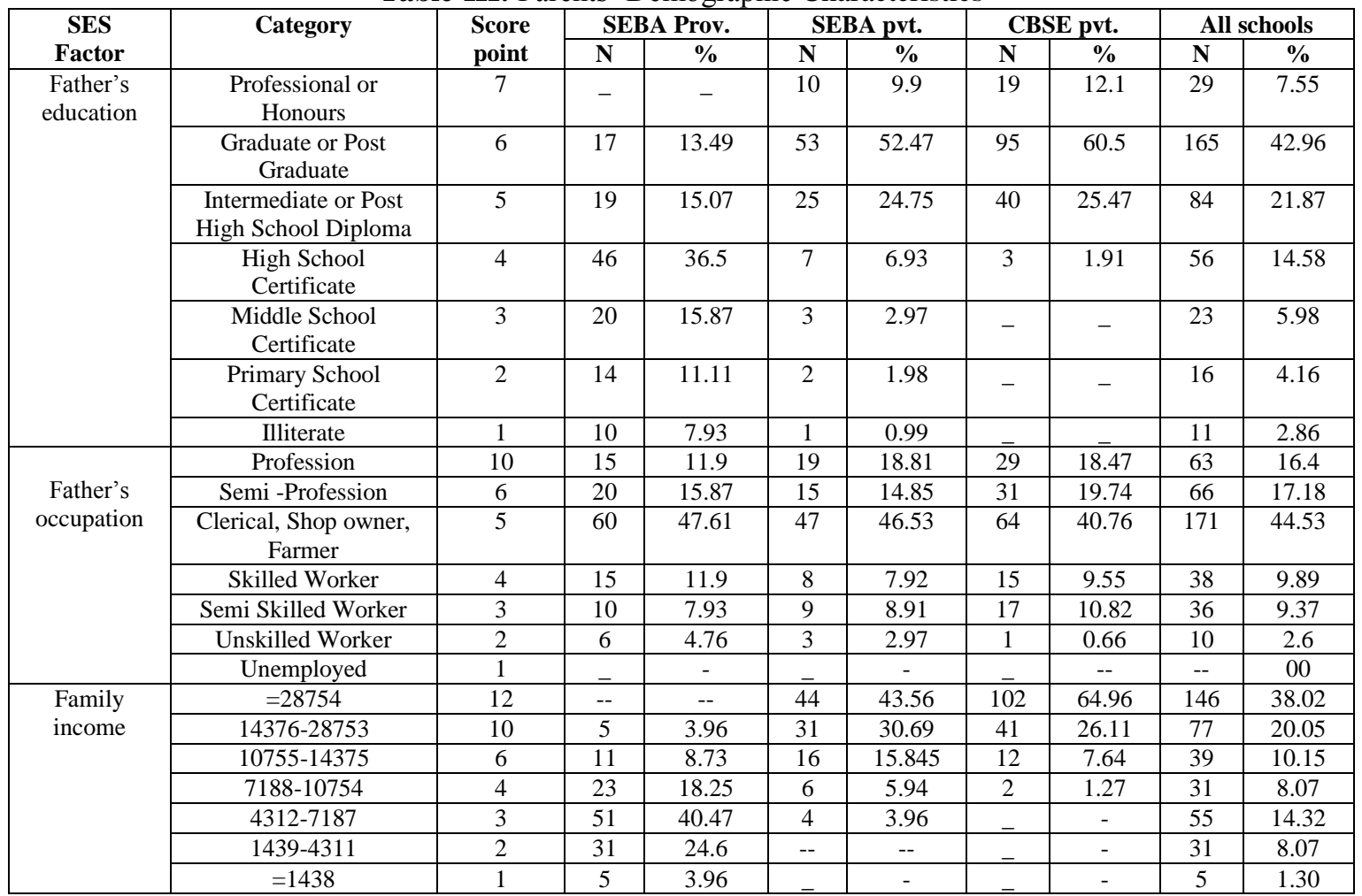

\section{Analysis And Interpretation}

In the Table III of distribution of students from SEBA (Prov.), SEBA (Pvt.) and CBSE (Pvt.) it is revealed that $22.7 \%$ of SEBA (pvt.) and $26.7 \%$ students of CBSE (Pvt.) are from upper class. There is no student in the upper class from SEBA (Prov.) schools under the study. From upper middle class there are $9.52 \%$ from SEBA (Prov), $67.3 \%$ from SEBA (Pvt.) and $64.3 \%$ from CBSE (Pvt.). Students distribution in lower middle class is $40.5 \%$ from SEBA (Prov), $7.9 \%$ from SEBA (Pvt.) and $8.9 \%$ from CBSE (Pvt.). Similarly in upper lower class $41.3 \%$ from SEBA (Prov), $1.9 \%$ from SEBA (Pvt.), but no students from CBSE (Pvt.). Finally in lower class there was no student from SEBA (Pvt.) and CBSE (Pvt.) however, there is $8.7 \%$ of students from SEBA (Prov). The association between the students of various categories of schools on SES was found to be significantly related (chi-square=237.061; df-8; sig. level 0.01). 
Effect of Socioeconomic status on performance in Mathematics among students of secondary ..

Table-IV: Sample distribution on SES of different categories of school

\begin{tabular}{|c|c|c|c|c|c|c|c|c|c|}
\hline \multirow{2}{*}{ SES } & \multicolumn{2}{|c|}{ SEBA (Prov.) } & \multicolumn{2}{|c|}{ SEBA(Pvt.) } & \multicolumn{2}{|c|}{ CBSE(Pvt.) } & \multicolumn{2}{|c|}{ Total } & Chi-square \\
\hline & $\mathbf{N}$ & $\%$ & $\mathbf{N}$ & $\%$ & $\mathbf{N}$ & $\%$ & $\mathbf{N}$ & $\%$ & \multirow{7}{*}{$237.061^{* *}$} \\
\hline $\mathrm{UC}$ & _ & 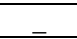 & 23 & 22.77 & 42 & 26.75 & 65 & 16.93 & \\
\hline UMC & 12 & 9.52 & 68 & 67.33 & 101 & 64.33 & 181 & 47.14 & \\
\hline LMC & 51 & 40.48 & 8 & 7.92 & 14 & 8.92 & 73 & 19.01 & \\
\hline ULC & 52 & 41.27 & 2 & 1.98 & _ & - & 54 & 14.06 & \\
\hline LC & 11 & 8.73 & - & - & - & - & 11 & 2.86 & \\
\hline Total & 126 & 100.0 & 101 & 100.0 & 157 & 100.0 & 384 & 100.0 & \\
\hline
\end{tabular}

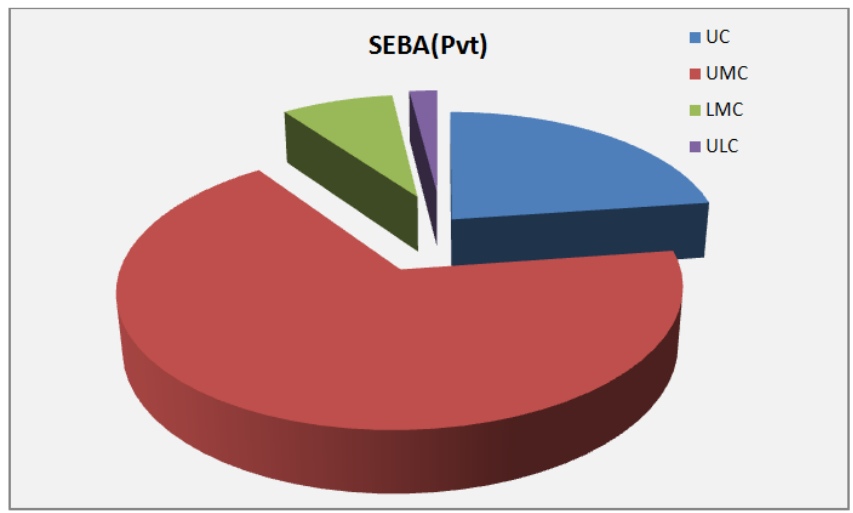

Fig 1: Distribution of SEBA (Pvt.) students on SES on SES

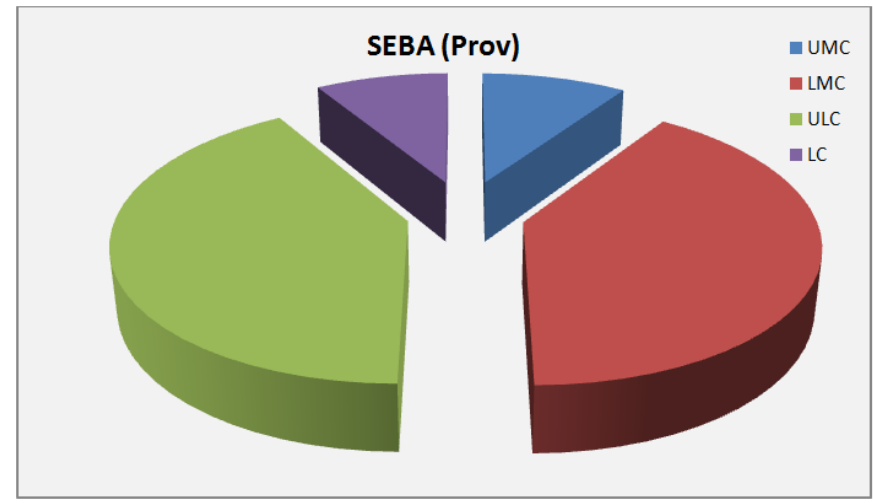

Fig 2: Distribution of SEBA (Prov) students

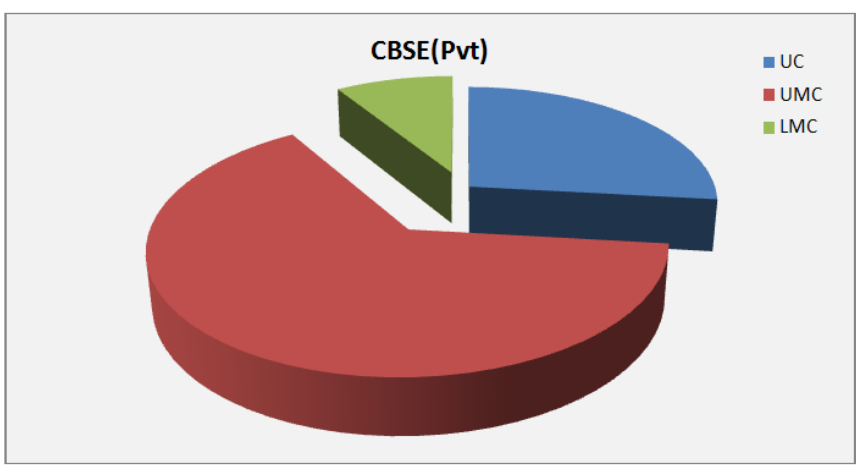

Fig 3: Distribution of CBSE (Pvt) students on SES

ANOVA is run to examine if there is difference between mean 'socio-economic status' scores of students from different categories of schools. The Table-V reveals the result of one way ANOVA analysis. This analysis was performed on SES of the students of different categories of schools which are SEBA (Prov), SEBA (Pvt.) and CBSE(Pvt.). As found $p<0.001$ the test is significant.

Therefore, there is evidence to reject the null hypothesis of no difference in means, i.e. the students from three different categories of schools like SEBA (Prov), SEBA (Pvt.) and CBSE (Pvt.) schools differ significantly on their SES. 
Effect of Socioeconomic status on performance in Mathematics among students of secondary ..

Table-V: One way ANOVA Types of Socio-Economic Status

\begin{tabular}{|c|c|c|c|c|c|}
\hline & $\begin{array}{c}\text { Sum of } \\
\text { Squares }\end{array}$ & Df & $\begin{array}{c}\text { Mean } \\
\text { Square }\end{array}$ & F & Sig. \\
\hline Between Groups & 136.320 & 2 & 69.110 & \multirow{2}{*}{178.512} & 0.000 \\
\cline { 1 - 4 } Within Groups & 159.264 & 381 & 0.403 & & \\
\hline Total & 295.414 & 383 & & & \\
\hline
\end{tabular}

Table VI: Distribution of students on SES with performance level in mathematics

\begin{tabular}{|c|c|c|c|c|c|c|c|c|c|c|c|c|}
\hline \multirow{2}{*}{ Class } & \multicolumn{2}{|c|}{ Excellent } & \multicolumn{2}{c|}{ Very good } & \multicolumn{2}{c|}{ Good } & \multicolumn{2}{c|}{ Satisfactory } & \multicolumn{2}{c|}{ Unsatisfactory } & \multicolumn{2}{c|}{ Total } \\
\cline { 2 - 14 } & $\mathbf{N}$ & $\mathbf{\%}$ & $\mathbf{N}$ & $\mathbf{\%}$ & $\mathbf{N}$ & $\mathbf{\%}$ & $\mathbf{N}$ & $\mathbf{\%}$ & $\mathbf{N}$ & $\mathbf{\%}$ & $\mathbf{N}$ & $\mathbf{\%}$ \\
\hline UC & 11 & 2.86 & 22 & 5.73 & 12 & 3.13 & 11 & 2.86 & 9 & 2.34 & 65 & 16.93 \\
\hline UMC & 35 & 9.11 & 69 & 17.97 & 53 & 13.80 & 13 & 3.39 & 11 & 2.86 & 181 & 47.14 \\
\hline LMC & 15 & 3.90 & 19 & 4.95 & 23 & 5.99 & 11 & 2.86 & 5 & 1.3 & 73 & 19.01 \\
\hline ULC & 3 & 0.78 & 16 & 4.17 & 12 & 3.13 & 17 & 4.43 & 6 & 1.56 & 54 & 14.06 \\
\hline LC & - & - & - & - & - & - & 3 & 0.78 & 8 & 2.08 & 11 & 2.86 \\
\hline Total & 64 & 16.67 & 126 & 32.81 & 100 & 26.04 & 55 & 14.32 & 39 & 10.16 & 384 & 100 \\
\hline
\end{tabular}

Table VII: Classification on performance level

\begin{tabular}{|c|c|}
\hline Levels of performance & Scores \\
\hline Excellent & $80-100$ \\
\hline Very good & $60-79$ \\
\hline Good & $40-59$ \\
\hline Satisfactory & $30-39$ \\
\hline Unsatisfactory & Below 30 \\
\hline
\end{tabular}

Table VIII: Performance level, types of socioeconomic status, school category

\begin{tabular}{|c|c|c|c|c|c|c|c|}
\hline \multirow[t]{2}{*}{ School Category } & \multirow[t]{2}{*}{ Performance level } & \multicolumn{5}{|c|}{ Types of socio-economic status } & \multirow[t]{2}{*}{ Total } \\
\hline & & $\mathbf{U C}$ & UMC & MC & LMC & $\mathbf{L C}$ & \\
\hline \multirow[t]{6}{*}{ CBSE(Pvt.) } & Excellent & 5 & 20 & 3 & 0 & 0 & 28 \\
\hline & Very good & 10 & 30 & 5 & 0 & 0 & 45 \\
\hline & Good & 6 & 30 & 4 & 0 & 0 & 40 \\
\hline & Satisfactory & 11 & 12 & 2 & 0 & 0 & 25 \\
\hline & Unsatisfactory & 10 & 9 & 0 & 0 & 0 & 19 \\
\hline & Total & 42 & 101 & 14 & 0 & 0 & 157 \\
\hline \multirow[t]{6}{*}{ SEBA(Prov) } & Excellent & 0 & 4 & 5 & 1 & 0 & 10 \\
\hline & Very good & 0 & 8 & 23 & 8 & 2 & 41 \\
\hline & Good & 0 & 0 & 20 & 16 & 0 & 36 \\
\hline & Satisfactory & 0 & 0 & 2 & 20 & 3 & 25 \\
\hline & Unsatisfactory & 0 & 0 & 1 & 7 & 6 & 14 \\
\hline & Total & 0 & 12 & 51 & 52 & 11 & 126 \\
\hline \multirow[t]{6}{*}{ SEBA(Pvt.) } & Excellent & 4 & 18 & 3 & 1 & 0 & 26 \\
\hline & Very good & 12 & 22 & 5 & 1 & 0 & 40 \\
\hline & Good & 5 & 19 & 0 & 0 & 0 & 24 \\
\hline & Satisfactory & 1 & 4 & 0 & 0 & 0 & 5 \\
\hline & Unsatisfactory & 1 & 5 & 0 & 0 & 0 & 6 \\
\hline & Total & 23 & 68 & 8 & 2 & 0 & 101 \\
\hline
\end{tabular}

Table IX: Performance level, types of socio-economic status, school category

\begin{tabular}{|c|c|c|c|c|c|c|c|}
\hline \multirow{2}{*}{$\begin{array}{c}\text { School } \\
\text { category }\end{array}$} & \multirow[t]{2}{*}{ Performance level } & \multicolumn{5}{|c|}{ Types of socio-economic status } & \multirow[t]{2}{*}{ Total } \\
\hline & & $\mathrm{UC}$ & UMC & $\mathrm{MC}$ & LMC & $\mathrm{LC}$ & \\
\hline \multirow{6}{*}{$\begin{array}{l}\text { All the } \\
\text { schools }\end{array}$} & Excellent & 11 & 35 & 15 & 3 & 0 & 64 \\
\hline & Very good & 22 & 69 & 19 & 16 & 0 & 126 \\
\hline & Good & 12 & 53 & 23 & 12 & 0 & 100 \\
\hline & Satisfactory & 11 & 13 & 11 & 17 & 3 & 55 \\
\hline & Unsatisfactory & 9 & 11 & 5 & 6 & 8 & 39 \\
\hline & Total & 65 & 181 & 73 & 54 & 11 & 384 \\
\hline
\end{tabular}




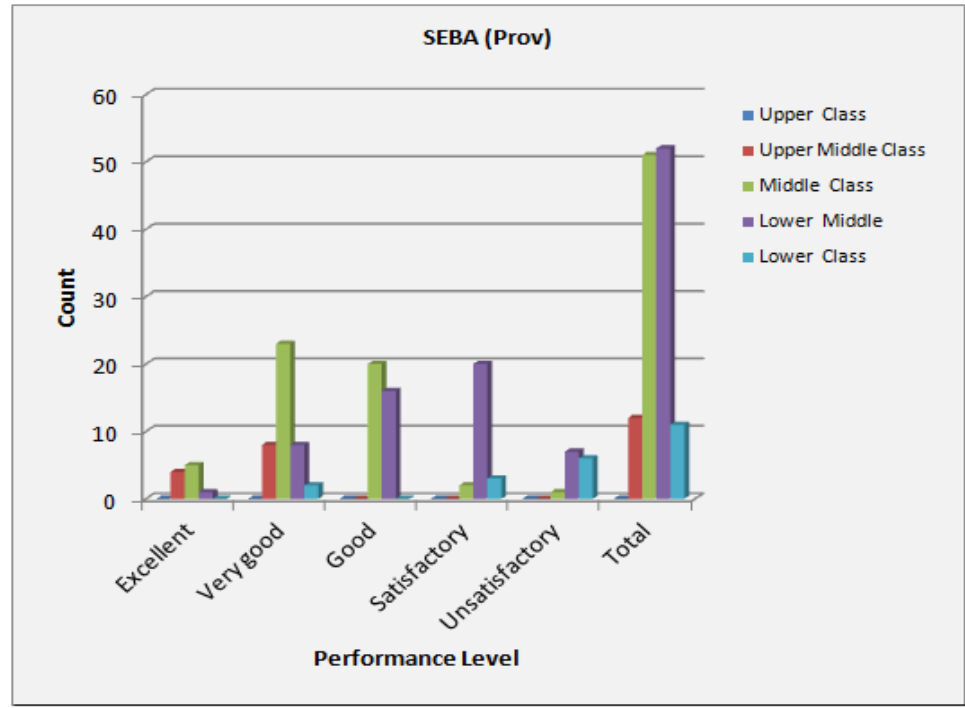

Fig 4: Performance level and SES of CBSE (Pvt.)

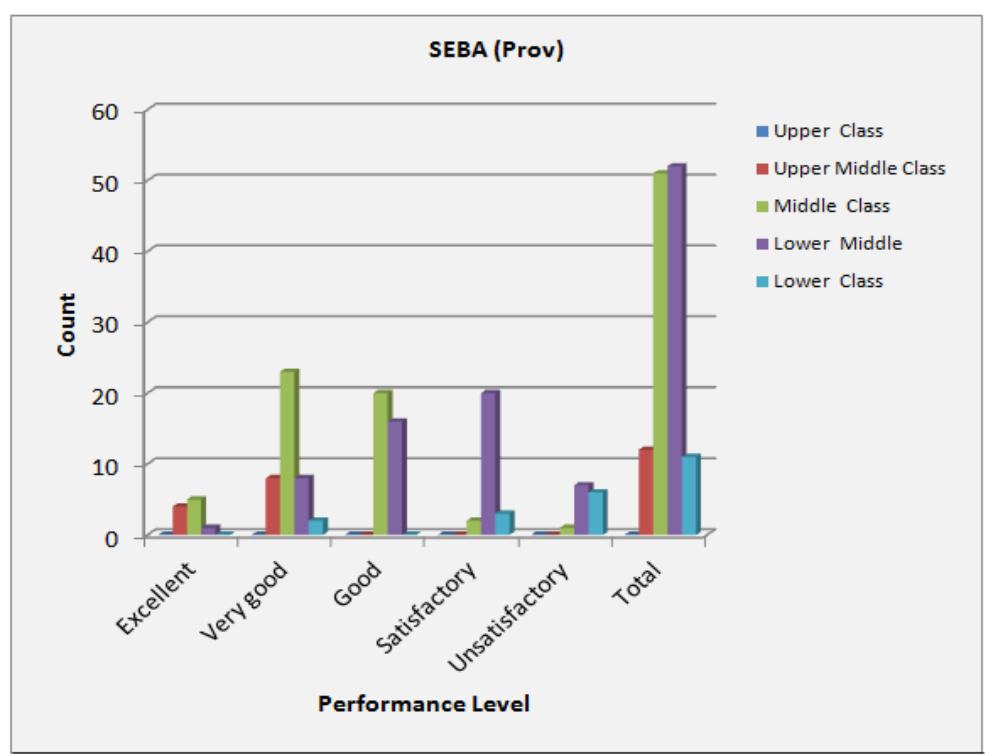

Fig 5: Performance level and SES of SEBA (Prov)

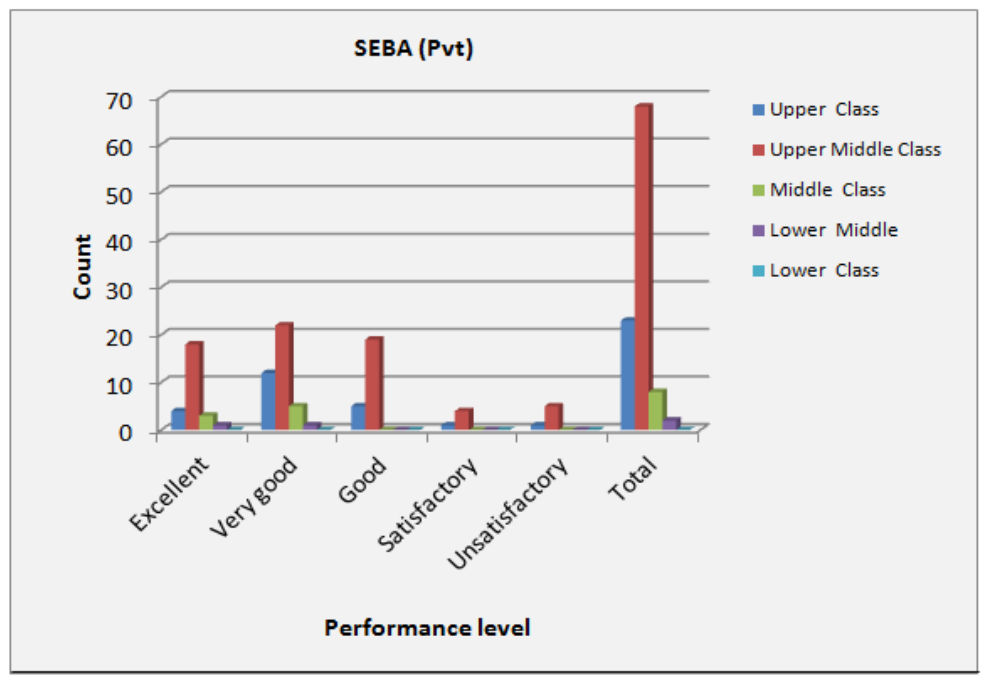

Fig 6: Performance level and SES of SEBA (Pvt.) 


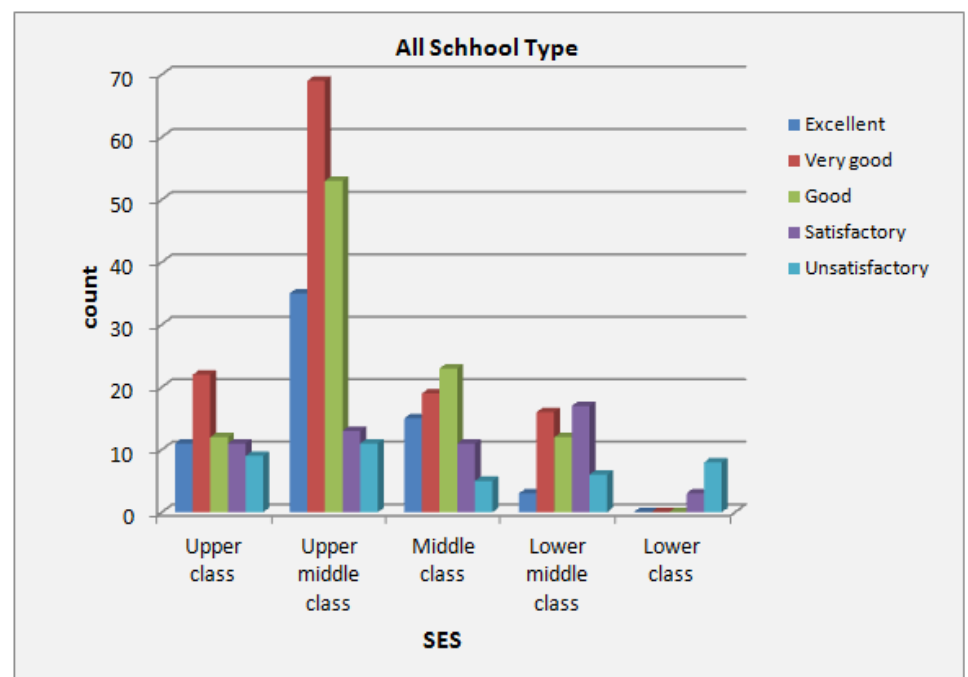

Fig 7: Performance level and SES of all schools

Table X: Chi-square analysis

\begin{tabular}{|c|c|c|}
\hline Category of School & Chi-square value & Significance ( 2 sided) \\
\hline CBSE(Pvt.) & 7.142 & 0.657 \\
\hline SEBA(Prov) & 15.212 & 0.335 \\
\hline SEBA(Pvt.) & 5.923 & 0.594 \\
\hline Over all & 63.729 & 0.000 \\
\hline
\end{tabular}

From the outputs we can reveal that the chi-square statistic for the students of CBSE was found 7.142 with $p$-value of 0.657 which is not significant. So, there is no evidence to reject the null hypothesis that there is no association between SES and students performance in mathematics in this group.

The chi-square statistic for the students of SEBA (Prov) was found 15.212 with $p$-value of 0.335 which is not significant revealing that there is no evidence to reject the null hypothesis that there is no association between SES and students performance in mathematics in this group.

The chi-square statistic for the students of SEBA(Pvt.) was found 5.923 with $p$-value of 0.594 which is not significant. It reveals that there is no evidence to reject the null hypothesis that there is no association between SES and students performance in mathematics in this group. But, overall the chi-square statistic is found to be 63.729 with a $p$-value of 0.000 , which is significant. Therefore, there is evidence to reject the null hypothesis that there is no association between SES and students performance in mathematics in this group.

Table XI: Correlation of SES and performance in mathematics

\begin{tabular}{|c|c|}
\hline Components of SES & r-value \\
\hline Fathers educational qualification & $0.198^{*}$ \\
\hline Fathers occupation & $0.213^{*}$ \\
\hline Monthly family income & $0.302^{*}$ \\
\hline SES & $0.298^{*}$ \\
\hline
\end{tabular}

* Significant correlation at the 0.01 level (2-tailed)

Table XI reveals that the socio economic status of the students' parents are positively correlated with the performance of the students in mathematics. In the components of SES like Fathers educational qualification, Fathers occupation and Monthly family income, the correlation was found to be positive with their children's performance in mathematics at 0.01 level of significance.

Table XII: One way ANOVA Students' performance levels in mathematics

\begin{tabular}{|c|c|c|c|c|c|}
\hline & Sum of squares & $\mathrm{df}$ & Mean square & F & Sig \\
\hline Between groups. & 66.025 & 4 & 14.031 & \multirow{3}{*}{11.518} & \multirow{2}{*}{0.000} \\
\hline Within groups & 520.305 & 379 & 1.304 & & \\
\hline Total & 61.236 & 383 & & \\
\hline
\end{tabular}

ANOVA was performed on the students' performance in mathematics from all the five classes of family where p-value was found to be significant (Table- XII ). Therefore, there is evidence to reject the null hypothesis of no difference in means, i.e., the students from the various classes differ significantly on their performance in mathematics. 


\section{Findings}

1. The socio-economic status of the students of three different categories of schools under the study is significantly different.

2. The socioeconomic status significantly affects students' performance in mathematics from different categories of schools under the study.

3. There is a significant relationship between the components of socioeconomic status such as father's income, occupation, monthly family income and students' performance in mathematics.

\section{Conclusions}

The study intends to observe the effect of socio-economic status of parents on their children's performances in mathematics. The study attained at a conclusion in this respect that the socio-economic status of parents affects children's performances in mathematics. Observation of the components of socio-economic status of parents leads to state that the components such as father's education, occupation and monthly family income also affect independently children's performance in mathematics.

So, the concerned policy makers should try to put an emphasis for the upliftment of the socio economic status of lower and lower middle classes so that the children are enriched in the subject. Parents also should be parallely and effectively concerned for the all round improvement of their children. Moreover, as most of the students of government provincialised schools are from lower middle class, government should take effective initiatives in standardization of academic side with other facilities.

\section{Acknowledgement}

We extend our deepest gratitude to the management of Assam down town University for unwavering support. At the same time we are thankful to Professor H K Sarma, department of mathematics of GU for his true encouragement.

\section{References}

[1]. Telford, C.W. and Sawrey, J.M. : Educational Psychology, $2^{\text {nd }}$ Edition, New Delhi, Prentice Hall Of India (private) Ltd (1964).

[2]. Jeynes, William H. : Examining The Effects Of Parental Absence On The Academic Achievement Of Adolescents: The Challenge Of Controlling For Family Income, Journal Of Family and Economic Issues (2002), 23(2).

[3]. Hochschild, Jennifer L. : Social Class In Public Schools, Journal Of Social Issues (2003). 59(4), 821-840.

[4]. Grewal, A. : An International Study Of Cognitive And Socioeconomic Correlations Of School Achievement, J. Psy. Res. (1985), 29(1):41-45.

[5]. Velz, E., Schiefelbein, E. \& Valenzuella, J. : Factors Affecting Achievement In Primary Education, Washington, DC: Human Resources Development And Operations Policy, The world bank (working paper series) (1993).

[6]. Sirin, S. R. (2005). Socioeconomic status and academic achievement: A metaanalytic review of research. Review of Educational Research, 75(3), 417-453.

[7]. White, K. R. (1982). The relation between socioeconomic status and academic achievement. Psychological Bulletin, 91(3), 461-481.

[8]. Mueller, C. W., \& Parcel, T. L. (1981). Measures of socioeconomic status: Alternatives and recommendations. Child Development, 52(1), 13-30

[9]. Bornstein, M. H., \& Bradley, R. H. (Eds.). (2003). Socioeconomic status, parenting, and child development. Mahwah, NJ: Lawrence Erlbaum Associates

[10]. Gottfried, A. (1985). Measures of socioeconomic status in child development research: Data and recommendations. Merrill-Palmer Ouarterly, 31(1), 85-92.

[11]. Hauser, R. M. (1994). Measuring socioeconomic status in studies of child development. Child Development, 65(6), 1541-1545.

[12]. Sarmah, H. K. \& Hazarika, B. B. : A Study On The Effect Of Socio-Economic Status On Interest In Mathematics Among Students Of Different Categories Of Guwahati, International Journal Of Statistics And Analysis (2013), Vol.3, No. 1, pp. 51-75.

[13]. Choudhari, V. S., Vaidya, Navalakha, N.G. and Mahapatra B.C. : Effect Of Teaching Strategies And Socioeconomic Status On Self Concept Of The Learner, Indian Psy. Review (1998), 50(4):216-223.

[14]. Khan and Jemberu : Influence Of Family Socio- economic Status On Educational And Occupational Aspirations Of High And Low Achieving Adolescents, J.Com.Guid. Res. 19(1):113-118.

[15]. Kumar N, Shekhar C, Kumar P, Kundu A.S. : Kuppuswamy's Socioeconomic Status Scale-Updating For 2007, Indian J Pediatr (2007), 74: 1131-2.

[16]. Mishra, D., Singh, H.P. : Kuppuswamy's Socioeconomic Status Scale-A Revision, Indian J. Pediatr (2003), 70:273-4.

[17]. Santos, J.R.A. : Cronbach's Alpha: A Tool For Assessing The Reliability Scales, Journal Of Extention $37(2)$, Retrieved $15^{\text {th }}$ March, 2016 from http:// www.joe.org/joe/1999 April/ tt3. 